ENCYCLOPÉDIE Encyclopédie berbère

BERBERE

8 | 1990

8 | Aurès - Azrou

\title{
Azref : « droit coutumier »
}

(pl. izerfan), (Maroc central)

\section{S. Chaker}

\section{OpenEdition}

\section{Journals}

Édition électronique

URL : http://journals.openedition.org/encyclopedieberbere/227

DOI : $10.4000 /$ encyclopedieberbere.227

ISSN : 2262-7197

\section{Éditeur}

Peeters Publishers

\section{Édition imprimée}

Date de publication : 1 juillet 1990

Pagination : 1223

ISBN : 2-85744-461-3

ISSN : $1015-7344$

\section{Référence électronique}

S. Chaker, « Azref : « droit coutumier » », Encyclopédie berbère [En ligne], 8 | 1990, document A350, mis en ligne le 20 avril 2011, consulté le 25 septembre 2020. URL : http://journals.openedition.org/ encyclopedieberbere/227 ; DOI : https://doi.org/10.4000/encyclopedieberbere.227

Ce document a été généré automatiquement le 25 septembre 2020.

(c) Tous droits réservés 


\section{Azref : «droit coutumier »}

(pl. izerfan), (Maroc central)

\section{S. Chaker}

$1 \quad$ Var. : izref

2 Terme désignant dans les parlers berbères de la zone tamaziyt (Maroc central) l'ensemble des règles des codes coutumiers. c'est donc le vocable proprement berbère correspondant au lexème kabyle d'emprunt (l-)qanun, d'origine grecque, à travers l'arabe.

3 Voir : droit coutumier.

\section{BIBLIOGRAPHIE}

LAOUST E., Cours de berbère marocain (Maroc central), Rabat, 1924, p. 381.

MERCIER G., Vocabulaire et textes berbères (Ait Izdeg), Rabat, 1937, p. 89.

INDEX

Mots-clés : Droit, Maroc 